Research Article

\title{
Distribution, Nutritive Value and Mineral Composition of a Few Medicinal Plants of Shimoga District, Karnataka India
}

\author{
Sarala P*, Krishnamurthy S.R \\ Department of P.G. Studies and Research in Applied Botany, Kuvempu University, Shankaraghatta, India. \\ *Corresponding author's E-mail: saralap2007@yahoo.co.in
}

Received: 25-05-2021; Revised: 28-07-2021; Accepted: 05-08-2021; Published on: 15-08-2021.

\begin{abstract}
An attempt has been made to determine proximate, nutritive value, elemental composition and heavy metal contents of different flowers and fruits samples. The flowers and fruits samples were analyzed with the help of standard procedure. Among the macro elements nitrogen, potassium, calcium was dominant and phosphorus, magnesium was lowest in the respective fruit samples. The micronutrients study reveals that iron was the dominant element and manganese and copper was the lowest elements. Of the six proximates, moisture and carbohydrates was dominant and protein and fiber was the lowest in the different fruit samples. The highest value of nutritive value was recorded in the fruit sample of $S$. anacardium and lowest value of nutritive value was recorded in the fruit samples of $B$. frondosa. The average values of proximate, nutritive values were compared with recommended dietary allowances (RDA) values and discussed. Further, fruits and flowers help to development of ayurvedic formulation and to established cottage industries to improve economic and social condition of local people are appended.
\end{abstract}

Keywords: Butea frondosa Koen, Elemental composition, Nutritive value, Medicinal plants, Terminalia chabula Retz.

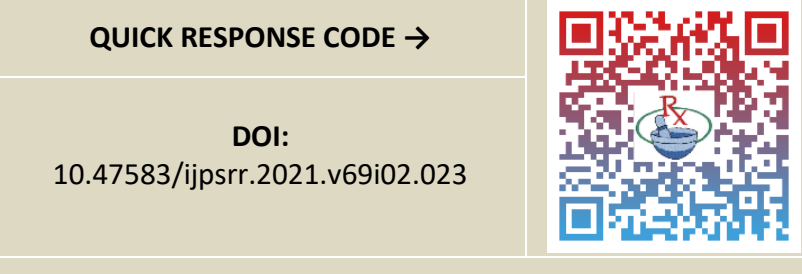

DOI link: http://dx.doi.org/10.47583/ijpsrr.2021.v69i02.023

\section{INTRODUCTION}

$\mathrm{N}$ ow-a-days animals and plants are suffering from numerous diseases, due to the lack of nutrition (Ash, moisture, fat, fiber, protein and carbohydrates) mineral ( $\mathrm{Na}, \mathrm{K}, \mathrm{Ca}, \mathrm{Mg}, \mathrm{P}, \mathrm{Zn}, \mathrm{Cu}, \mathrm{Mn}, \mathrm{Fe}$ ) and vitamins supplements. The specific deficiency of nutritional compounds, mineral components and vitamins causes the specific disorders like zinc deficiency causes pneumonia. ${ }^{1}$ Vitamin $D$ deficiency causes osteoporosis, heart diseases, muscle and bone pain with undiagnosed causes, multiple sclerosis, rheumatoid, arthritis and various forms of cancer including breast, colon and prostate. ${ }^{2-9}$ Herbal drugs have been used by mankind since time immemorial to treat various disorders and offer an alternative to the synthetic compounds as they have been considered either non-toxic or less toxic. The traditional Indian system of medicine, ayurveda (Ayu-life, vedaknowledge) extensively uses the plant derived compound formulations for the treatment of various ailments after a careful study into the type of the disease. Plants are complex mixtures of compounds and no single compounds potentiate a desired therapeutic action while others reinfore the same and yet others interact to neutralize and counteract any possible side effects that may exist. Therefore, several plants with the common desired activities and varied undesirable activities are selected so that the final formulation will have a concentrated desired activity and the undesired activities will be diluted or absent altogether. ${ }^{10-13}$ Triphala is one of the ayurvedic formulation commonly prescribed by most health care practitioners in India. It is a traditional ayurvedic formulation consisting of the equal proportional mixture of dried fruits of three medicinal plants Amalaki (Emblica officinals), Haritaki (Terminalia chebula) and Bibhitaki (Terminalia bellerica) and also known as' three myrobalan. Triphala means three (tri) fruits (phala). It is wild, non-habit forming and rejuvenates and hence is recommended for all. ${ }^{14}$ Tripala exhibits antiviral, antibacterial, antifungal and ant allergic properties and its constituents act as cardio tonic, control blood pressure, improve blood circulation and reduce cholesterol levels. Triphala shows immune modulator properties and helps in improving the body's defense system. In recent years there are also several reports in the literature which suggest that triphala possess anti nut generic radio protecting and antioxidant activity. ${ }^{15}$

T.chabula is belongs to family combreataceae it is used in fevers, cough, asthma, urinary diseases, piles, worms and rheumatism and scorpion sting. It is used in the preparation of triphala churna and has adjuncts to other medicines in numerous diseases like rheumatism . ${ }^{16}$

Terminalia bellerica fruits are useful in coughs, hoarseness, eye diseases and scorpion sting. It is used for preparation of Triphala churna, this churna is prescribed in diseases of the liver and gastro-intestinal tract and in a large variety of diseases. Kernel is narcotic and astringent and is used as an application to inflamed parts. Dried ripe fruit is astringent 
and employed in dropsy, piles and diarrhoea and also occasionally in fever. Gum is demulcent and purgative. ${ }^{16}$

Emblica officinalis is belongs to family Euphorbiaceae. The fresh fruit is of the lungs and of the eves as a collyrium. In Persia it is used as vermifunge. The green fruits are made into pickles and preserves to stimulate appetite. This is a nutritive tonic useful in phthisis, and improves all conditions of debility. The drug is also used in scorpionsting. ${ }^{16}$

Sapindus trifoliatus is belongs to family Sapindaceaec. The seed of Sapindus trifoliatus is used to stimulate the uterus to child birth and in amenorrhea. Seeds pounded up with water and introduced into the mouth cut short the paroxysm of epilepsy.

Semicarpus anacardium is belongs to the family Anacardace. The tree is large handsome with a spanicles of small yellow male flower and inconspicuous greenish females. Wood is soft grayish- white, and useful. Fruit it is used for strength of teeth. The seed oil is specific in rheumatism.

Butea frondosa is belongs to the family Fabaceae. Bark furnishes a very important exudation which hardens into a red brittle resin known as butea gum or Bengal kino. Medicinally it is an excellent astringent, useful in diarrhoea and dysentery. Fresh juice is also applied to ulcers and relaxed. Congested and septic sore throat; internally it is given in diarrhoea dysentery and phthisis. As anthelmintic and aperients. Flowers are used for dyes. Seeds are useful in ring worn, herpes, bark is given with ginger in snake bites. A week decoction of the bark is useful in catarrh, cold and cough. ${ }^{16}$ In the present study, medicinally important plants of Terminalia chebula, Terminalia bellerica, Emblica officinalis Sapindus trifoliatus, Semicarpus anacardium and Butea frondosa were taken for investigation from the different places of Shimoga district. ${ }^{17}$ It is the three constituents that is Amalaki, Bibhitaki and Harataki represents these three humors Amalaki is related with pitta humor, so it helps treating inflammatory complications, liver problems, ulcers, constipation, diarrhea, infections and many others. Apart from that, Amalaki offers its significant role as antibacterial and antiviral substance, pronounced expectorant and cardiovascular nourishment tonic. Bibhitaki corresponds to kapha humor. It helps treating asthma, allergies, coughs and bronchiole complications. Haritaki is linked with vata humor. It is helpful in treating chromic constipation of these three constituents. ${ }^{18}$ All of these constituents have been studied scientifically and the result confirms the traditional benefits of the same. In total, it is one of the best ayurvedic rasayana or preparation that others an excellent solution for lowering cholesterol level, reducing high blood pressure, enhancing blood circulation, improving digestive system and managing eradication without being dependent on laxatives. Each of the fruit components of Triphala takes a great care of the body system by promoting gentle purification of all toxic elements of the body, while improving the digestive system throughout. Due to its ability to nourish internal organs of the body. It resembles the care of the mother to her child. With its high nutritional value, it cleanses the body at the deepest organic level without running down the reserves of the body system. That makes the preparation one of the best among all herbal mediations in the world. ${ }^{15}$ It exhibits antiviral, antibacterial, antifungal and antiallergic properties. ${ }^{16-17}$ Triphala and its constituents act as cardio tonic, control blood pressure, improve blood circulation and reduce cholesterol levels. Triphala shows immune modulators properties and helps in improving the body's defense system. In recent years there are also several reports in the literature which suggest that triphala possess ant mutagenic radio protecting and antioxidant activity. ${ }^{18-19}$ Kumar et al. showed that radio protective effects of Rasayanas..$^{20}$ Rama Sundaran Srikumar et al., studied effect of Triphala an oxidative stress and on cell-mediated immune response against noise stress in rats. ${ }^{21}$ Recently, Naik et al. ${ }^{22}$ studied free radical scavenging reactions and phytochemical analysis of Triphala, an ayurvedic formulation and Rukmini and Udaya shankara Rao studied the chemical and nutritional values of kernel and its oil of Terminalia bellerica Roxb. Is a valuable tree of Indian forests. ${ }^{23}$ However, with the nutritional values and elemental composition of fruits of components of Triphala. ${ }^{24}$ In the present study, medicinally important plants of Terminalia chebula, Terminalia bellerica, Emblica officinalis Sapindus trifoliatus, Semicarpus anacardium and Butea frondosa were taken for investigation from the different places of Shimoga district.

\section{MATERIALS AND METHODS}

\section{Study Area}

Shimoga district lies towards the North-western part of Karnataka state. It is situated between $13^{\circ} 27^{\prime}$ to $14^{\circ} 39^{\prime}$ North latitude and $74^{\circ} 38^{\prime}$ to $76^{\circ} 4^{\prime}$ East longitude. The district stretches $154 \mathrm{kms}$ East-West direction and $128 \mathrm{~km}$ in North South direction. The district is bordered by Davangere district in the East, Chikmagalur in the south and Dharwad district in the North. On the North-West border, North Canara and on the south-west by South Canara (Map 1).

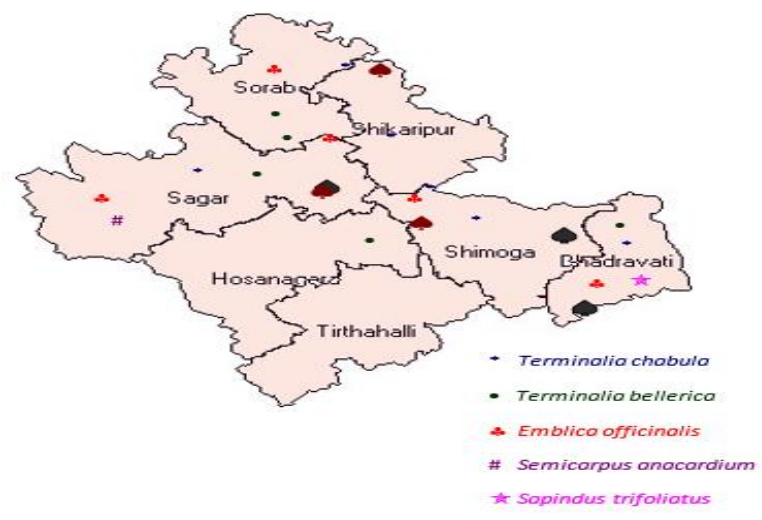

Map 1. Distribution of medicinal plants in various taluks of Shimoga district 
The main rivers of the district are the Tunga, Bhadra and Sharavathi. The river Tunga runs in most part of the district. It joins with Bhadra at Kudli. The Sharavathi flows towards North-West taking its origin near Kavale Durga. It hurls down the Ghat at Jog. Creating the world famous Jog falls. The Gargita river originates a Kodachadri and flows downward towards South Canara through Haidar Ghar Ghat. There are several tanks in the district. Of these, the Shantisagar tank is the largest. As greater part of the district consists of several mountains covered by thick forest, the climate is very agreeable. The average rainfall of the district is $827 \mathrm{~cm}$ towards western side and $90 \mathrm{~cm}$ towards the Eastern boundary. The rainy season extend from May-June to October-November, December-April practically there is no rain. The hottest period is between March to May (http://en.wikipedia.org.Karnataka). ${ }^{25}$

\section{Collection of plants and distribution}

The medicinal plants were collected and distribution study was made on the basis of regular field visits. The plants were collected and materials were brought to the laboratory and technical descriptions were made on the basis of observations. The plant were identified and assigned them to the respective taxonomy position. Simultaneously, various taxonomical literatures were also referred to confirm their distribution and identity. ${ }^{26-29}$

\section{Medicinal values}

The medicinal uses of identified plants were documented on the basis of literature. ${ }^{30-32}$

\section{Preparation of plant sample for analysis}

The collected plants were carried to the laboratory as quickly as possible using polythene bags. The samples were washed with the help of camel hairbrush and sponging with a piece of cotton wool in a $0.1 \%$ detergent solution or dilute $(0.1 \% \mathrm{~N}) \mathrm{HCl}$ to remove the adherent dust particles, then it was rinsed into lots of distilled water and remove the excess of water from the plant surface using blotting paper or ordinary filter paper and separated the flowers and fruits portions for separate analysis, cut the plant sample into pieces of suitable size. After cleaning, the sample was shade dried in a dust fume free place, not sun light because nitrogen fractions may be lost through volatilization. Then material was shade dried it was grinded to fine powder using pestle and mortar to avoid contamination (Plate-1). Then powder was preserve in an air tight bottles (jars) or pressing covers and store the material under the refrigerated condition for further analysis of nutrients. ${ }^{33-37}$

\section{Determination of Nutritive Value}

\section{Determination of Ash content}

$10 \mathrm{~g}$ of each sample was weighed in a silica crucible. The crucible was heated first over a low flame till all the material was completely charred, followed by heating in a muffle furnace for about 3 to $5 \mathrm{~h}$ at $600^{\circ} \mathrm{C}$. It was cooled in a desiccator and weighed to ensure completion of ashing.
It was heated again in the furnace for half an hour, cooled and weighed. This was repeated constantly till the weight become constant (ash become white or grayish white) Weight of the ash giving the ash content. ${ }^{33-37}$

$$
\text { Ash } \%=\frac{\text { Loss of weight of sample }}{\text { Initial weight of sample }} \times 100
$$

\section{Determination of moisture content}

The sample materials were taken in a flat bottom dish and kept overnight in an air oven at $100-110^{\circ} \mathrm{C}$ and weighed. The loss in weight was regarded as a measure of moisture content (NISCOM, CSIR, 1999). The per cent of moisture has been calculated using the following formula. ${ }^{33-37}$

$$
\begin{aligned}
& \text { Moist content } \%=\frac{\text { Loss of weight of sample }}{\text { Initial weight of plant sample }} \times 100 \\
& \text { Determination of crude fat }
\end{aligned}
$$

The crude fat determined by extracting $2 \mathrm{gm}$ of moisture free sampling with petroleum ether in a Soxhlet extractor, heating the flask on a sand-bath for about $6 \mathrm{~h}$ till a drop taken from the drippings left no greasy stain on the filter paper. After boiling with petroleum ether (Chopra and Kanwar, 1991) and the residual petroleum ether was filtered using Whatman No. 40 filter paper and the filtrate was evaporated in a pre-weighed beaker. Increase in weight of beaker gave the crude fat. The percent of crude fat has been calculated by using the following formula. ${ }^{33-}$ 37

$$
\text { Crude fat } \%=\frac{\text { Weight of the crude fat }}{\text { Weight of the plant material }} \times 100
$$

\section{Determination of crude fiber}

The crude fibre was determined by titrating the moisture free and fat free materials were treated with $200 \mathrm{ml}$ of $1.25 \%$ sulfuric acid. After filtration and washing, the residue was treated with $1.25 \%$ of sodium hydroxide solution. It was filtered, washed with hot water and then $1 \% \mathrm{HNO}_{3}$ and again with hot water. The residue was ignited and the ash was weighed. The loss in the weight gave the weight of the crude fibre (Chopra and Kanwar, 1991). The percent of crude fibre can be calculated by using the following formula. ${ }^{33-37}$

Crude fibre $\%=\frac{\text { Weight of the ash }}{\text { Weight of the plant material }} \times 100$

\section{Protein Estimation by Lowry's method}

\section{Sample preparation}

Extraction was carried out with buffer used for the enzymes assay. 500mg of sample was taken and grind by using pestle and mortar in 5-10 $\mathrm{ml}$ of the buffer, then centrifuged and used the supernatant for protein estimation. 


\section{Estimation of protein}

Pipette out $0.2,0.4,0.6,0.8$ and $1 \mathrm{ml}$ of working standard solution was taken in a series of test tube. Then 0.1 and 0.2 $\mathrm{ml}$ of plant sample was pipetted out in two other test tubes and make up the volume to $1 \mathrm{ml}$ with distilled water taken as blank. Then added $5 \mathrm{ml}$ of regent $\mathrm{C}$ to each tube including the blank and mixed well and allowed to stand for $10 \mathrm{~min}$. Then added $0.5 \mathrm{ml}$ of reagent $D$ again mixed well and incubated at room temperature in the dark for 30 min then blue colour was developed. The reading was taken at $660 \mathrm{~nm}$ and a standard graph was drawn and calculated the amount of protein in sample. ${ }^{33-37}$

\section{Determination of carbohydrate}

The percent of carbohydrate was calculated by using the following formula as follows,

Carbohydrate $\%=100-[$ ash $\%+$ moist $\%+$ fat $\%+$ protein \%]

\section{Determination of nutritive value}

The percent of nutritive value was calculated by using the following formula as follows,

Nutritive value $\%=4 x$ protein $\%+9 x$ fat $\%+4 x$ carbohydrate \%

\section{Preparation of plant Sample for mineral Analysis}

One gram of powdered dried plant material was taken in $250 \mathrm{ml}$ of conical flask 25 to $35 \mathrm{ml}$ of diacid mixture (900 $\mathrm{ml} \mathrm{HNO}+400 \mathrm{ml}$ perchloric acid) was added, each conical flask was closed by using funnels. Then digestion was carried out by using hot plates at $1 \mathrm{~h}$ upto get clear solution at 10 minutes then added $50 \mathrm{ml}$ of distilled water and filtered by using Whatman filter paper. After completion of filtration, the content was transferred quantitatively to $100 \mathrm{ml}$ of volumetric flask and final volume was adjusted to $100 \mathrm{ml}$ by adding distilled water. This solution was ready for mineral analysis. ${ }^{33-37}$

\section{Determination of Macronutrients}

\section{Determination of sodium and potassium}

\section{Principle of flame photometry}

The aliquot of plant digest containing alkali and alkaline earth metallic cations is fed to the flame photometry, it vaporizes to gaseous state. The compound dissociates into individual atoms which get excited due to the heat energy of flame. On the excited the electrons jumps from its normal orbit to higher energy level. The excitation state of

$$
\% \text { of } \mathrm{Na} / \mathrm{K}=\frac{\text { Graph ppm }}{10^{6}} \times \text { Dilution factor } \times
$$

Determination of phosphorus in the plant samples by vanado-molybdate yellow colour method

Principle the atom does not remain for longer time as it is unstable, it reverts to its original level. While returning to its original state, the atom loses the energy in the form of radiation. The characteristic colour and wave length of the radiation indicates the type of the element. Yellow coloured radiation with $589 \mathrm{~nm}$ wave length indicates presence of sodium and red coloured radiation with wave length 766 $\mathrm{nm}$ indicates the presence of potassium. ${ }^{33-37}$

\section{Materials and reagents required}

1) $250 \mathrm{ml}$ beaker with glass rod.

2) $100 \mathrm{ml}$ volumetric flask.

3) Pipettes 1, 2, 5 and $10 \mathrm{ml}$.

4) 1 litre volumetric flask.

5) $50 \mathrm{ml}$ volumetric flask.

6) Electric or chemical balance

\section{Preparation of sodium standards}

1000 pm sodium stock solution was prepared by dissolving $0.6304 \mathrm{gm}$ of pure dried sodium chloride in distilled water. $100 \mathrm{ppm}$ sodium stock solution was prepared by diluting $10 \mathrm{ml}$ of $1000 \mathrm{ppm}$ sodium stock solution. The various working sodium standard solution of $0,1,2,3,4$ and 5 ppm were prepared with suitable dilution.

\section{Preparation of potassium standards}

$1000 \mathrm{pm}$ sodium stock solution was prepared by dissolving $1.908 \mathrm{gm}$ of pure dried $\mathrm{KCl}$ in distilled water. $100 \mathrm{ppm}$ sodium stock solution was prepared by diluting $10 \mathrm{ml}$ of $1000 \mathrm{ppm}$ sodium stock solution. The various working sodium standard solution of $0,1,2,3,4$ and 5 ppm were prepared with suitable dilution.

\section{Procedure}

$2 \mathrm{ml}$ of aliquot plant digested material was taken in $50 \mathrm{ml}$ volumetric flask and make up the volume adding distill water. This gives a dilution factor of 50 . Then adjusting the flame photometer reading to ' 0 ' with ' 0 ' ppm standard and 100 with 5 ppm standard solution and flame photometer reading for other standard feeding the diluted solution of plant digested and recorded the flame photometer. Reading and draw the standard curve of sodium / potassium by plotting the flame photometer readings along with the $y$-axis and concentration along with the $x$ axis, detect the concentration of $\mathrm{Na} / \mathrm{K}$ in the curve. ${ }^{33-37}$

The $\%$ of $\mathrm{Na} / \mathrm{K}$ was calculated with the help of following formula.

$\frac{\text { Volume of plant digestion made }}{\text { Weight of the plant sample }} \times 100$

Orthophosphate (phosphorus) present in the plant digest when react with vanadate and molybdate gives a yellow coloured complex i.e. phospho-vanadomolybdate in acid solution. The yellow colour due to the substitution of 
oxyvanadium and oxymolybdenum radicals for oxygen of $\mathrm{PO}_{4}$ to give a heteropoly compound. The intensity of yellow colour is measured colourimetrically at 400 to $490 \mathrm{~nm}$ using spectrophotometer.

\section{Reagents required}

Vanadomolybdate reagent (Ammonium molybdateAmmonium vanadate in nitric acid).

\section{Preparation of solution A}

Dissolve $1.25 \mathrm{~g}$ ammonium metavanadate in $300 \mathrm{ml}$ of boiling water. Cool and add $250 \mathrm{ml}$ of concentrated $\mathrm{HNO}_{3}$ and again cool to room temperature.

\section{Preparation of solution B}

Dissolve $25 \mathrm{~g}$ of ammonium molybdate in $400 \mathrm{ml}$ of distilled water pour solution $A$ to solution $B$ mix well and make up the volume to 1 litre with distilled water.

\section{Preparation of phosphorus standards}

\section{Preparation}

Prepare $100 \mathrm{ppm}$ of $\mathrm{P}$ standard stock solution by dissolving $0.2195 \mathrm{~g}$ of pure $\mathrm{KH}_{2} \mathrm{PO}_{4}$ in $500 \mathrm{ml}$ of distilled water.

\section{Working standards of phosphorous}

Transfer 0, 1, 2, 2.5, 5, 7.5 and $10 \mathrm{ml}$ of 100 ppm P-stock solution into separate $50 \mathrm{ml}$ volumetric flask to get $0,2,5$, 10,15 and 20 ppm of P-working standards.

\section{Procedure}

Transfer $5 \mathrm{ml}$ of aliquot of plant digest (Triacid or diacid digested plant samples) into $50 \mathrm{ml}$ volumetric flask. Add 10 $\mathrm{ml}$ of vanadomolybdate reagent to samples and also to each standards and mix thoroughly and make up the volume to $50 \mathrm{ml}$ with distilled water. After 30 minutes of colour development read the intensity of yellow colour on a spectrophotometer at $470 \mathrm{~nm}$ (i.e., between 400-490 $\mathrm{nm}$ ).Draw the calibration curve (standard graph) of $\mathrm{P}$ standards by plotting the $\mathrm{P}$-absorbance against $\mathrm{P}$ concentration. $^{33-37}$

i. Find out the P-content in plant digest sample by referring to the standard curve.

\section{Calculation}

The $\%$ of $P$ in the plant sample was calculated with a help of following formula.

$$
\% \text { of } \mathrm{P}=\frac{\text { Graph ppm }}{10^{6}} \times \frac{\text { Volume of dilution made }}{\text { Aliquot }} \times \frac{\text { Volume of plant digest }}{\text { Weight of plant sample }} \times 100
$$

\section{Determination of calcium and magnesium}

\section{Procedure}

$1 \mathrm{ml}$ of aliquot plant digested material was taken in $50 \mathrm{ml}$ of volumetric flask and $10 \mathrm{ml}$ of vanadomolybdate reagent was added and mixed thoroughly and final volume was adjusted to $50 \mathrm{ml}$ by adding distilled water. Feed the sample to AAS and observe the results with the help of

$$
\% \text { of } \mathrm{Ca} / \mathrm{Mg}=\frac{\text { Graph ppm }}{10^{6}} \times \text { Dilution factor } \times \frac{\text { Volume of plant digestion made }}{\text { Weight of the plant sample }} \times 100
$$

\section{Determination of Nitrogen}

\section{Principle}

Nitrogen content of plant was converted into $\left(\mathrm{NH}_{4}\right)_{2} \mathrm{SO}_{4}$ by digesting with diacid mixture (concentrated $\mathrm{H}_{2} \mathrm{SO}_{4}$ ). The acid digest was distilled for ammonia by using $40 \% \mathrm{NaOH}$. The distilled ammonia was trapped in boricacid mixed indicator solution. The amount of ammonia trapped was estimated by titrating against standard acid.

\section{Reagents}

1) Concentrated $\mathrm{H}_{2} \mathrm{SO}_{4}$ or diacid mixture (9:4= $\mathrm{HNO}_{3}: \mathrm{HClO}_{4}$ (Perchloric acid)

2) $40 \% \mathrm{NaOH}$

3) $2 \%$ or $4 \%$ boric acid

4) $0.01 \mathrm{~N} \mathrm{H}_{2} \mathrm{SO}_{4}$

5) Mixed indicator (Bromeresol green) (0.1g) + Methyle red $(0.07 \mathrm{~g})$ in $100 \mathrm{ml}$ of $95 \%$ of ethanol. calcium / magnesium hallow cathode lamp with a wave length 422.7 and $28.2 \mathrm{~nm}$ of calcium / magnesium. Draw the calibration curve with the help of concentration value. 33-37

The \% of Ca / Mg was calculated with the help of following formula.

Transfer $15 \mathrm{ml}$ of mixed indicator to 1 litre of boric acid. Adjust the boric acid mixed indicator solution to the bluish purple midcolour at $\mathrm{pH} 4.5$ by using diluted $\mathrm{HCl}$ or $\mathrm{NaOH}$ $(0.1 \mathrm{~N})$ to get sharp end point. This indicator is pink at a $\mathrm{pH}$ 4.2 bluish, purple midcolour at $\mathrm{pH} 4.5$ and bluish green as the $\mathrm{pH}$ rises to 4.9 or above when ammonia is trapped.

\section{Procedure}

$1 \mathrm{gm}$ of powdered dried plant material was taken in Kjeldhal or nitrogen digestion flask $25 \mathrm{ml}$ of concentrated $\mathrm{H}_{2} \mathrm{SO}_{4}$ and 2 or 3 spatula of diacid mixture were added. The digestion was carried out on a low flame initial for 10 to 15 min until frothing stops. The digestion at high temperature was carried out for 1 to $1 \frac{1}{2} \mathrm{~h}$ or till the content of Kjeldal flask become clear the flask was cooled and the contents was transferred the quantitatively to $100 \mathrm{ml}$ of volumetric flask and final volume was adjusted to $100 \mathrm{ml}$ by adding distilled water. 
$10 \mathrm{ml}$ of diluted acid digested sample was taken in a micro Kjeldal distillation assembly. Boric acid mixed indicator solution was kept at ready at the receiving end to trap ammonia, $30 \mathrm{ml}$ of $40 \% \mathrm{NaOH}$ was added and distillation was carried out till the colour of the mixture changes from bluish purple to bluish green further the distillation is also continued to for some of time to trap the all the ammonia, released. The completion of distillation was confirmed by using litmus test in which no changes in colour of the red litmus paper indicate the complete distillation. The quantity of ammonia distilled was estimated by titrating against $0.01 \mathrm{~N} \mathrm{H}_{2} \mathrm{SO}_{4}$ or $\mathrm{HCl}$ till the colour changes to purple. ${ }^{33-37}$

The $\%$ of $\mathrm{N}$ was calculated with the help of following formula.

$$
\% \text { of Nitrogen }=\frac{\text { Titrate value } \times \mathrm{N} \mathrm{H}_{2} \mathrm{SO}_{4} \times 0.014 \times \text { dil factor (if any) }}{\text { Weight of plant sample }(\mathrm{g})} \times 100
$$

\section{Determination of Micronutrient cations in plant sample by using Atomic Absorption Spectrophometery (AAS)}

Micronutrients namely $\mathrm{Zn}, \mathrm{Fe}, \mathrm{Cu}$ and $\mathrm{Mn}$ were analyzed from the plant samples with the help of AAS. The digested samples which were prepared for the elemental analysis are used with the following modifications.

The $2 \mathrm{ml}$ of digested samples were taken and diluted to 50 $\mathrm{ml}$ and the following micronutrients are analyzed.

\begin{tabular}{|c|c|c|}
\hline SI. No. & $\begin{array}{c}\text { Name of } \\
\text { micronutrients }\end{array}$ & $\begin{array}{c}\text { Wavelength of the } \\
\text { lamp (nm) }\end{array}$ \\
\hline 1 & Zinc & 213.9 \\
\hline 2 & Manganese & 279.5 \\
\hline 3 & Iron & 248.3 \\
\hline 4 & Copper & 324.75 \\
\hline
\end{tabular}

Finally, the values of micronutrients are expressed in ppm by the help of following formula:

$\begin{aligned} & \text { ppm of } \\ & \begin{array}{l}\text { micronutrients } \\ \text { in plant }\end{array}\end{aligned} \frac{\mathrm{ppm}}{1000} \times \frac{\text { Vol. of plant digest }}{\text { Weight of the plant sample }} \times$ Dilution factor $\times 1000$

\section{Analysis of Cadmium and Lead}

In addition to micro and macro-elements, cadmium and lead were also analyzed. The procedures and calculations are followed as described in the micro elemental analysis. ${ }^{33-37}$

\section{RESULTS AND DISCUSSION}

Of the six medicinal plants which were studied for distribution, mineral composition and nutritive value was discussed (Table 1 and 2).

Terminalia chabula Retz.(Fig 5.A.) Ramaswamy et al., ${ }^{27} 2001$ reported the four species of Terminalia form Shimoga district. The plant is reported from Ullur of Sagar taluk, where plant is scatteredly found in associated with Xylia xylocarpa (Roxb.) Taub. and Holarrhena antidysenterica (Roth.) DC however, the plant is very rare in the Kuvempu University campus. It is also found in Srilanka, Indomalaya, Burma and Kampuchea. Terminalia bellerica Roxb (Fig 5.B) is recorded in the deciduous forests of all districts of Madras presidency up to the altitude of 3,000 ft. Ramaswamy et al., ${ }^{27} 2001$ recorded Terminalia bellerica in the forest of Kattinakere of Sorab taluk, Ullur of Sagar taluk and Gajanur of Shimoga taluk of Shimoga district and they have observed in the distribution Terminalia bellerica often in association with Terminalia crenulata (Roxb.) Roth. and Ervatamia heyneana (Wall.) Cooke. The plant is frequently found in the Kuvempu University campus which belongs to Bhadra Wildlife Sanctuary. Sri Rambhat (1992-1993) 28 recorded Terminalia bellerica from Kodachadri forest of Shimoga district. Gamble $(1998)^{26}$ classify species of Emblica officinalis Gaertn (Fig 5.C.) and Emblica fischer (Gamble, 1998) ${ }^{26}$.

Table 1: Distribution of medicinal plants in various taluks of Shimoga district

\begin{tabular}{|c|c|c|c|c|c|c|c|c|}
\hline \multirow{2}{*}{ SI. No. } & \multirow{2}{*}{ Name of the plants } & \multicolumn{7}{|c|}{ Taluk } \\
\hline & & Sagar & Sorab & Shikaripura & Thirthahalli & Bhadravathi & Shimoga & Hosanagara \\
\hline 1 & Terminalia chebula & + & + & No & + & + & + & + \\
\hline 2 & Terminalia bellerica & + & + & No & + & + & No & + \\
\hline 3 & Emblica officinalis & + & + & No & + & + & No & + \\
\hline 4 & Sapindus trifoliatus & - & - & - & - & - & - & - \\
\hline 5 & $\begin{array}{l}\text { Semicarpus } \\
\text { anacardium }\end{array}$ & + (Banajalaya) & - & - & - & - & - & - \\
\hline 6 & Butea Frondosa & + & + & No & + & + & + & + \\
\hline
\end{tabular}

Plants observed ; "-' Not seen ; No- Not observed. 
Table 2: Proximates, nutritive value, and mineral components of medicinal plants of Shimoga district

\begin{tabular}{|c|c|c|c|c|c|c|c|}
\hline SI No & Factors & T.chabula & T. bellerica & E.officinalis & S.trifoliatus & S anacardium & B.frandosa \\
\hline \multirow[t]{7}{*}{ I } & Macronutrients & & & & & & \\
\hline & $\mathrm{Na}$ & $1.56 \pm 0.18$ & $2.34 \pm 0.21$ & $3.13 \pm 0.88$ & $1.71 \pm 0.11$ & $1.81 \pm 0.10$ & $1.8 \pm 0.61$ \\
\hline & K & $4.04 \pm 0.05$ & $3.37 \pm 0.11$ & $3.07 \pm 0.06$ & $3.50 \pm 0.24$ & $1.73 \pm 0.20$ & $5.69 \pm 1.89$ \\
\hline & $P$ & $0.30 \pm 0.005$ & $0.34 \pm 0.018$ & $0.23 \pm 0.003$ & $0.69 \pm 0.017$ & $0.33 \pm 0.010$ & $0.54 \pm 0.18$ \\
\hline & $\mathrm{Ca}$ & $0.81 \pm 0.30$ & $3.50 \pm 0.30$ & $2.05 \pm 0.25$ & $0.52 \pm 0.22$ & $6.20 \pm 3.16$ & $1.19 \pm 0.28$ \\
\hline & $\mathrm{Mg}$ & $0.26 \pm 0.02$ & $0.36 \pm 0.01$ & $0.20 \pm 0.02$ & $0.41 \pm 0.02$ & $0.37 \pm 0.02$ & $0.87 \pm 0.02$ \\
\hline & $N$ & $3.55 \pm 0.05$ & $3.40 \pm 0.06$ & $4.36 \pm 0.02$ & $8.82 \pm 0.00$ & $2.17 \pm 0.02$ & $8.06 \pm 0.51$ \\
\hline \multirow[t]{5}{*}{ II } & Micronutrients & & & & & & \\
\hline & $\mathrm{Zn}$ & $88.00 \pm 14.14$ & $50.83 \pm 1.32$ & $46.35 \pm 2.49$ & $204.86 \pm 9.96$ & $89.71 \pm 6.22$ & $40.93 \pm 1.12$ \\
\hline & $\mathrm{Cu}$ & $40.94 \pm 2.23$ & $65.06 \pm 0.84$ & $65.06 \pm 4.41$ & $38.73 \pm 11.75$ & $29.24 \pm 3.61$ & $89.97 \pm 30.15$ \\
\hline & $\mathrm{Mn}$ & $23.41 \pm 1.52$ & $27.79 \pm 2.95$ & $565.52 \pm 7.22$ & $115.19 \pm 48.87$ & $561.85 \pm 44.30$ & $680.03 \pm 228.48$ \\
\hline & $\mathrm{Fe}$ & $870 \pm 8.11$ & $294.06 \pm 24.05$ & $139.28 \pm 7.57$ & $264.37 \pm 15.25$ & $910.48 \pm 331.43$ & $19.5 \pm 6.51$ \\
\hline \multirow[t]{4}{*}{ III } & $\begin{array}{l}\text { Lead and } \\
\text { Cadmium }\end{array}$ & & & & & & \\
\hline & $\mathrm{Pb}$ & - & - & - & - & - & - \\
\hline & $\mathrm{Cd}$ & - & - & - & - & - & - \\
\hline & $\begin{array}{l}\text { "+" indicates, "- } \\
\text { "Indicates not } \\
\text { detected }\end{array}$ & & & & & & \\
\hline \multirow[t]{8}{*}{ IV } & Nutritive value & & & & & & \\
\hline & Ash\% & $10.27 \pm 1.30$ & $10.90 \pm 0.55$ & $4.50 \pm 0.50$ & $11.80 \pm 1.68$ & $19.33 \pm 0.55$ & $19.50 \pm 0.50$ \\
\hline & Moisture\% & $166.10 \pm 0.68$ & $167.40 \pm 0.50$ & $83.20 \pm 4.60$ & $96.10 \pm 6.14$ & $108.00 \pm 12.17$ & $185.00 \pm 7.64$ \\
\hline & Fat $\%$ & 103.50 & $94.42 \pm 0.63$ & $4.50 \pm 0.26$ & $96.50 \pm 17.90$ & $96.50 \pm 17.90$ & $36.00 \pm 0.50$ \\
\hline & Fibre\% & $9.61 \pm 0.07$ & $6.24 \pm 1.62$ & $8.11 \pm 0.18$ & $3.00 \pm 000$ & $3.00 \pm 00$ & $13.28 \pm 5.78$ \\
\hline & Protein\% & $8.38 \pm 0.22$ & $6.94 \pm 0.03$ & $2.56 \pm 0.06$ & $3.67 \pm 0.03$ & $3.67 \pm 0.03$ & $1.44 \pm 0.06$ \\
\hline & $\begin{array}{c}\text { Carbohydrates } \\
\%\end{array}$ & $9.34 \pm 3.77$ & $20.26 \pm 0.96$ & $150.04 \pm 9.17$ & $100.25 \pm 27.39$ & $100.25 \pm 27.39$ & $53.39 \pm 7.50$ \\
\hline & $\begin{array}{l}\text { Nutritive Value } \\
\text { (in cal/100gm) }\end{array}$ & $940 \pm 1.69$ & $958.34 \pm 1.62$ & $882.90 \pm 2.93$ & $1174.08 \pm 73.69$ & $1117.08 \pm 73.69$ & $561.90 \pm 5.38$ \\
\hline
\end{tabular}

The species are classified on the basis of length of the branchlets shape of the fruits and the floral characteristic features. The Emblica officinalis was recorded in the North Circars, Deccan and Carnatic, where it was found in the dry deciduous forests of up to the altitude of $4,000 \mathrm{ft}$. The species is predominantly found in Mahendragiri and dry slopes of Western Ghats. It is important note that, though Gamble (1998) referred Emblica fischeri (Gamble, 1998) in the flora of Madras presidency, he referred that he did not observed the fruits. Ramaswamy et al., ${ }^{27}$ mentioned three species of Phyllanthus Linn. Emblica officinalis Gaertn observed in the deciduous forest of Humcha taluk of Shimoga district. The plant was scatteredly distributed. A few plants were observed in the premises of ladies hostel, top the Shankarghatta and behind the employment office of the Kuvempu University campus. Venugopal (1992$1993)^{29}$ recorded Phyllanthus emblica Linn. at Jade of Sorab taluk of Shimoga district. Butea frondosa Koen (Fig.5 E) (Gamble (1998) recorded to species of Butea frondosa
Koen and Butea superba Roxb was observed in the open country and deciduous forest perits of Deccan. The plants were common on black cotton soil and salts lands. The plant yields a red kinogum and lack insect is grown upon it. Butea superba Roxb. the leaves and flowers and pods were like those of Butea frondosa. However, the flower rather more yellow slight large than that of frondosa. The plant also yields kinogum and flowers yield red dye. Ramaswamy et al. (2001) ${ }^{27}$ reported Butea monosperma Lan, Butea frondosa Koening ex Roxb. and Plaso monosperma Lam Kuntzc. It was found in the Sampagodkan forest of Sorab taluk. Jog of Sagar taluk of Shimoga district. Sri Rambhat $(1994)^{28}$ reported Butea monosperma from Kodachadri forest and said that the plant is used as astringent. Sapindus trifoliatus Linn (Fig 5 D.) Gamble (1998) recorded two species of Sapindus Linn. Sapindus laurifolia vahal; which was recorded from Western Ghats of South canara and Mysore to the Anamalais and hills of Madura where it was found in the evergreen and open forests at low 
elevations he mentioned that the fruit is used like that of the soap. Pasakotta is the vernacular name of Malayalam. Sapindus emarginatus is observed North Circars, Deccan and Carnatic, extending into Eastern slopes of the Nilgriris and Pulneys and the hills of Tinnevelly of Madras presidency. The tree was frequently found in the deciduous and dry evergreen forests, frequent on the Coast of Striharikota in Nellore; it is also cultivated. The fruit is used for washing and commonly known as soap nut. The plant is observed between Kargal and Jog by Ramaswamy et al., 200127. The plant is planted in Kuvempu University Campus as avenue tree along the margin of the road side. Venugopal (1992-193) ${ }^{29}$ recorded from the village Sanda. Semicarpus anacardium Linn (Fig 5 F). Three species of Semicarpus anacardium Linn. were recorded from the Madras presidency (Gamble 1998) Semicarpus anacardium Linn. A moderate sized tree whose pericarp of the drupe gives a marking ink and hypocarp is edible.
Semicarpus travancorica Bedd which was recorded in the Western Ghats of evergreen forests of Travancore and Tinnevelly up to the altitude of 4,000ft. The plant is a large tree with grayish-white wood which has no value. Semicarpus anacardium was also observed in the evergreen forest of Travancore and Tinnevelly upto the altitude of $4,000 \mathrm{ft}$. The tree is large handsome with a panicles of small yellow male flowers and inconspicuous greenish females. Wood is soft grayish-white, and useful. Semicarpus anacardium the mark nut tree was found in the deciduous forests of all district of Madras Presidency. Ramaswamy et al., $2001^{27}$ recorded the plant at Bileshvara, Kattinakere, between Hosanagara and Sagar taluk of Shimoga district. The plant is scatteredly distributed in the deciduous forests. Venugopal (1992-1993) ${ }^{29}$ recorded Semicarpus anacardium Linn. at Marsa of sagar taluk and mentioned that the receptacle of fruit and seed oil and fruits are medicinally used (Map 1 and Table 1).
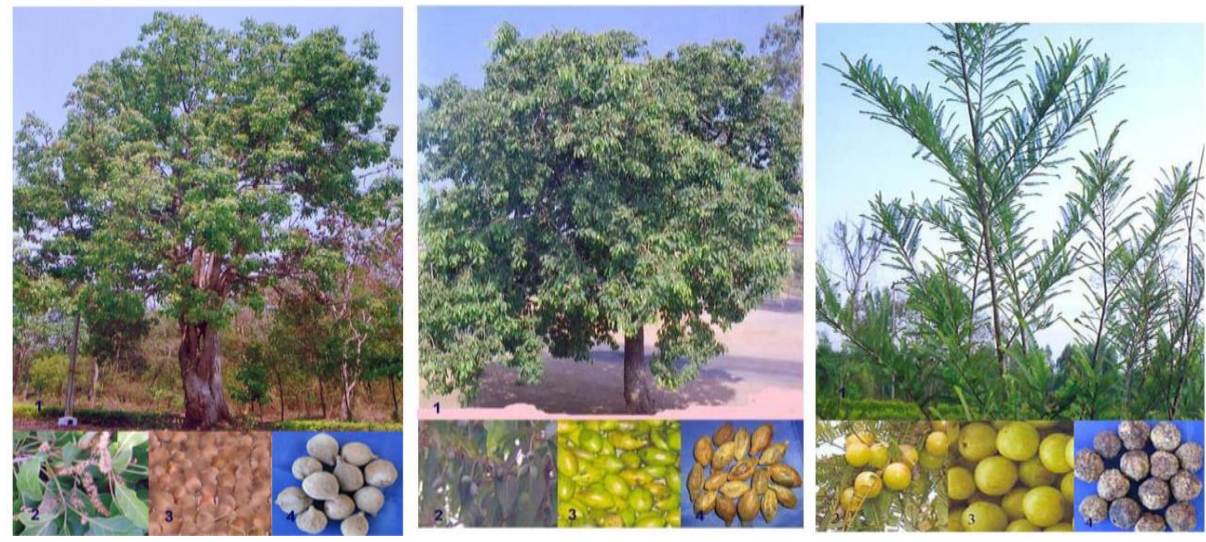

A. Terminalia chebula Retz. Roxb $\quad$ B. Terminalia bellerica Roxb. C. Emblica officinalis Garten.

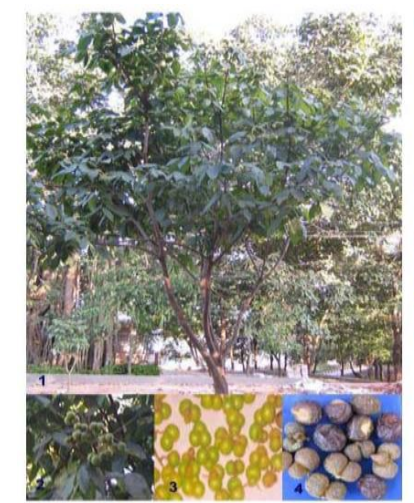

D. Sapindus trifoliatus Linn

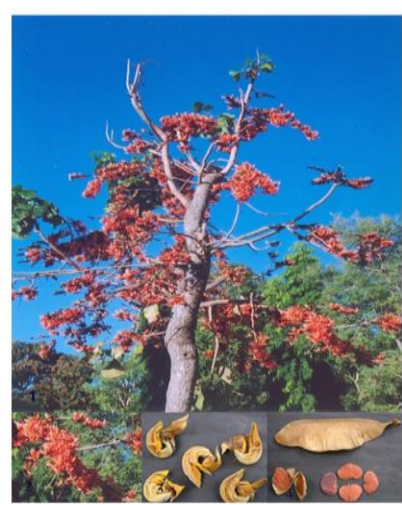

E. Butea frondosa Roxb.

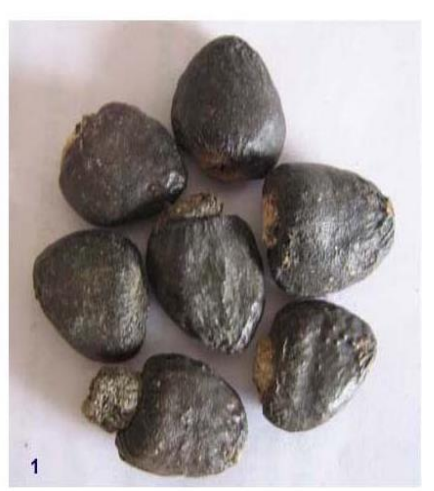

F. Semicarpus anacardium Linn

Figure 5: Medicinal plants of Shimoga district

\section{Macronutrients}

Of the six macronutrients, the highest percentage value of $3.13 \pm 0.88$ sodium was recorded in the fruit sample of E.officinalis and lowest percentage value of $1.56 \pm 0.18$ was recorded in the fruit sample of $T$. chabula, whereas in case of potassium the highest percentage value of 5.69 \pm 1.89 potassium was recorded in the flower sample of B.frondosa and lowest percentage value of $1.73 \pm 0.20$ potassium was recorded in the fruit sample of S.anacardium. The highest percentage value of $0.69 \pm$ 0.017phosphorus was recorded in the fruit sample of S.trifoliatus and lowest value of $0.23 \pm 0.003$ phosphorus was recorded in the fruit sample E.officinalis. The highest value of $6.20 \pm 3.16$ calcium was recorded in the fruit sample of S.anacardium and lowest value of $0.52 \pm 0.22$ calcium was recorded in the fruits of S.trifoliatus. The highest percentage value of $0.87 \pm 0.02$ Magnesium was recorded in the fruit sample $B$. frondosa and lowest value of $0.20 \pm 0.02$ was recorded in the fruit sample E.officinalies. The highest percentage value of $8.82 \pm 0.00$

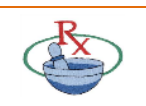


Nitrogen was recorded in the fruit sample of S.trifoliatus and lowest value of $2.17 \pm 0.02$ was recorded in the fruit sample of S.anacardium (Table 2 and Fig.1).

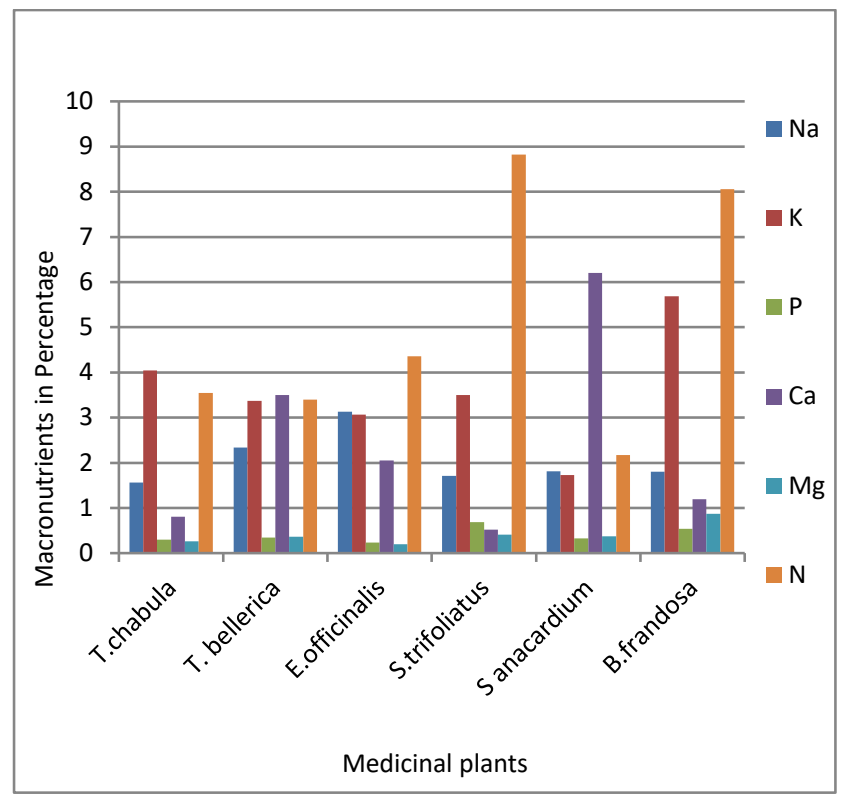

Figure 1: Variation of macro nutrients (\%) in different medicinal plants

T.chabula: Potassium $>$ Nitrogen $>$ Sodium $>$ Calcium $>$ Phosphrous > Magnesium

\section{T.bellerica:}

Calcium $>$ Nitrogen $>$ Potassium $>$ Sodium $>$ Magnesium $>$ Pho sphrous

\section{E.officinalies:}

Nitrogen $>$ Sodium $>$ Potassium $>$ Calcium $>$ Phosphrous

\section{S.trifoliatus :}

Nitrogen $>$ Potassium $>$ Sodium $>$ Potassium $>$ Calcium $>$ Mag nesium

\section{S. anacardium:}

Calcium $>$ Nitrogen $>$ Sodium $>$ Potassium $>$ Magnesium $>$ Phr ousphrus

\section{$B$ frondosa:}

Nitrogrn $>$ Potassium $>$ Sodium $>$ Calcium $>$ Magnesium $>$ Phosphorus

\section{T. chabula Iron $>$ Zinc $>$ Copper $>$ Manganese}

T. bellerica Iron $>$ Copper $>$ Zinc $>$ Manganese

\section{E. officinalis Iron>Zinc>Manganese>Copper}

\section{S. trifoliatus Iron>Zinc>Manganese>Copper}

S. anacardium Iron>Manganese $>$ Copperrtr5fr7i6tgf

\section{B. frondosa Manganese $>$ Copper $>$ Zinc $>$ Iron}

Of the four micronutrients the highest ppm of $204.86 \pm$ 9.96 zinc was recorded in the fruit sample of S.trifoliatus and lowest ppm of $40.93 \pm 1.12$ zinc was recorded in the fruit sample of $B$.frandosa. The highest ppm of $89.97 \pm$ 30.15 copper was recorded in the fruit sample of B.frandosa and lowest ppm of $29.24 \pm 3.61$ copper was recorded in the fruit sample of S.anacardium. The highest ppm of $680.03 \pm 228.84$ manganese was recorded in the fruit sample of $B$.frondosa and lowest ppm of 23.41 \pm 1.52 manganese was recorded in the fruit sample of T.chabula. The highest ppm of $910.48 \pm 331.43$ Iron was recorded in the fruit sample of S.anacardium and lowest ppm of $19.5 \pm 6.5$ Iron was recorded in the fruit sample of B.frondosa (Table 2 and Fig 2).

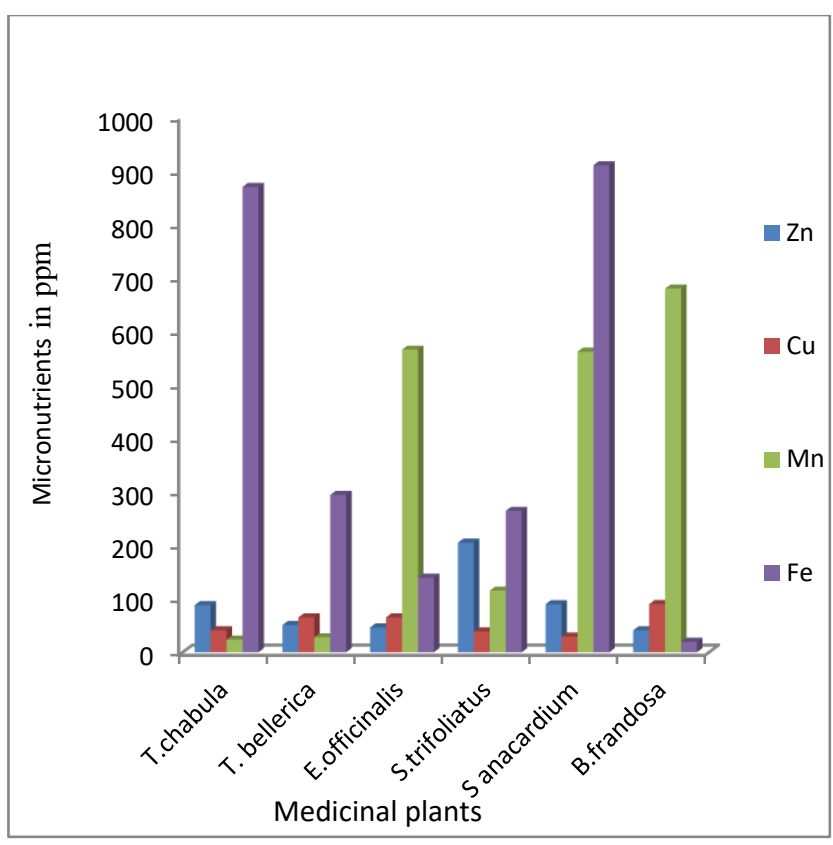

Figure 2: Variation of micro nutrients (ppm) in different medicinal plants

\section{Proximates and Nutritive value}

T.chabula

Moisture $>$ Fat $>$ Ash $>$ Protein $>$ Carbohydrates $>$ protein

T.bellerica

moisture $>$ Fat $>$ Protein $>$ Carbohydrates $>$ Ash $>$ Fibre

E.officinalies

Carbohydrates $>$ Moisture $>$ Ash $>$ Fat $>$ Fibre $>$ Protein

S.trifoliatus

Carbohydrates $>$ Fat $>$ Moisture $>$ Ash $>$ Protein $>$ Fibre

S.anacardium

Moisture $>$ Carbohydrates $>$ Ash $>$ Fat $>$ Protein $>$ Fibre

B.frondosa

Moisture $>$ Carbohydrates $>$ Fat $>$ Ash $>$ Fibre $>$ Protein

Nutritive value S.anacardium $>$ S trifoliatus $>$

T.bellerica $>$ T.chabula $>$ E. officinalis $>$ B. frondosa

The highest value of ash $19.50 \pm 0.50$ was recorded in the fruit sample of B.frondosa and lowest value of $10.27 \pm 1.30$ ash was recorded in the fruit sample of T.chabula. The highest value of $185.00 \pm 7.64$ moisture was recorded in the fruit sample of B.frandosa and lowest value of $83.20 \pm 4.60$ moisture was recorded in the fruit sample of E.officinalis. The maximum value of $103.50 \pm 7.63$ fat was recorded in the fruit sample of T.chabula and minimum value of $4.50 \pm 0.26$ fat was 
recorded in the fruit sample E.officinalis. The maximum value of $13.28 \pm 5.78$ fibre was recorded in the fruit sample of $B$.frondosa and minimum value of $3.00 \pm 0.00$ fibre was recorded in the fruit sample of S.trifoliatus. The highest value of $8.38 \pm 0.22$ of protein was recorded in the fruit sample of T.chabula and lowest value of $1.44 \pm 0.06$ protien was recorded in the fruit sample of $B$.frondosa. The maximum value of $150.04 \pm 9.17$ carbohydrates was recorded in the fruit sample of E.officinalis and minimum value of $20.26 \pm 0.96$ carbohydrates was recorded in the fruit sample of T.bellerica. The highest value of 1117.08 \pm 73.69 nutritive value was recorded in the fruit sample of S.anacardium and lowest value of $561.90 \pm 5.38$ was recorded in the fruit sample of $B$.frondosa (Table 2 and Fig 3, 4).

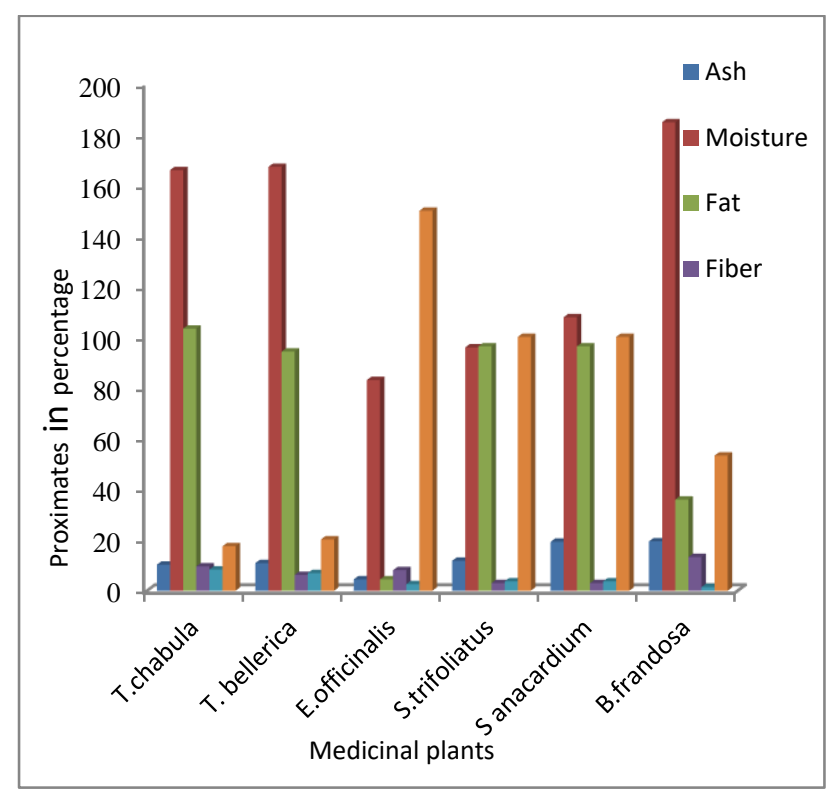

Figure 3: Variation of proximate (\%) in different medicinal plants

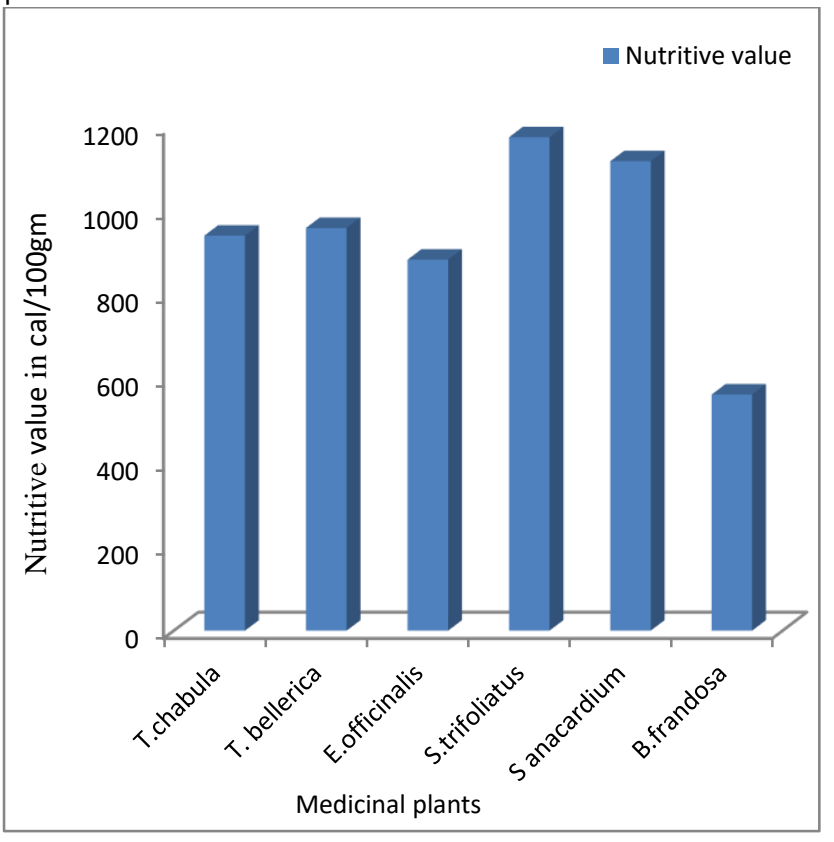

The result of the macronutrients, micronutrients, proximate and nutritive value is compared with recommended dilatory allowance (RDA) (Table 3).

Indrayana et al. (2005) $)^{11}$ said that $\mathrm{Na}$ and Ka take part in ionic balance of the human body and maintain tissue excitability. Because of the solubility of salt, Na plays an important role in the transport of metabolites. $\mathrm{K}$ is of important as a diuretic. Calcium constitutes a large proportion of the bone, human blood and extracellular fluid. It is necessary for the normal functioning of cardiac muscles, blood coagulation and milk clotting and the regulation of cell permeability. It also plays an important part in nerve impulse transmission and in the mechanism of neuromuscular system. $\mathrm{Mg}$ is required in the plasma and extracellular fluid where it helps maintain osmotic equilibrium. It is required in many enzyme catalyzed reactions especially those in which nucleotide participate where the reactive species in the magnesium salt example, MgATP2, lack of $\mathrm{Mg}$ is associated with abnormal irritability of muscle and convulsions and excess of $\mathrm{mg}$ with depression of the central nervous system. Further, Indrayana et al. $(2005)^{11}$ discussed the importance of sodium, potassium, calcium and magnesium of medicinally valued plants of Uttaranchal. Trace metals composition of food is of interest because of their essential toxic nature (Onianwa et al., 1999). ${ }^{38}$ Micronutrients constitute a small fraction of the entire diet but play important role in different metabolic processes (Akhter et al., 2002). ${ }^{39}$ Wide variations in concentrations of trace metals have been reported in bovillon cubes, mixed species and nuts (Akpasyung, 2005; Garcia et al., 2005 ; Satter et al., 1989 and Ansari et al., 2004)..$^{40-43}$

Micronutrients like namely $\mathrm{Zn}, \mathrm{Cu}, \mathrm{Mn}$ and Fe were analyzed in the parts which have been being used as of Terminalia chebula, Terminalia bellerica and Emblica officinalis. Mixture of medicinal plants are prescribed by the traditional healers for diseases ranging from common cold to malaria, arthritis, ulcers etc (Obiajunwa et al., 2002). ${ }^{44}$

The cadmium and lead was not recorded in the plant parts which are studied except in the fruit samples of Terminalia chebula and Terminalia bellerica in which traces of cadmium and lead was recorded. Lead and cadmium along with iron, $\mathrm{Mn}, \mathrm{Cu}, \mathrm{Ni}, \mathrm{Zn}$ etc., are also considered as heavy metals. Al Mourut Alukayode Ajasa et al. $(2003)^{45}$ studied heavy metals and macronutrient status in herbal plants of Nigeria (2004). Objunwa et al. (2002) studied essential and trace metals constituents of some Nigerian medicinal plants and reported that certain toxic elements such as lead, arsenic, mercury, cadmium etc., which are prime intact in toxicological study (War et al., 1996) were not found from the plant samples which they have studied.

Figure 4: Variation of Nutritive value (Cal/100gm) in different medicinal plants 
Table 3: Comparison of Recommended Dietary Allowances (RDA) with proximate, nutritive value and elemental composition of medicinal plants of Shimoga district

\begin{tabular}{|c|c|c|c|c|c|c|c|c|c|c|c|c|c|c|}
\hline \multirow{2}{*}{$\begin{array}{l}\text { SI } \\
\text { No }\end{array}$} & \multirow{2}{*}{ Factors } & & & & & & & \multicolumn{6}{|c|}{ RECOMMENDED DIETARY ALLOWANCES } & \multirow{3}{*}{ Refer } \\
\hline & & & & & & & & Females & Males & Females & Males & Females & Males & \\
\hline & & T.chabula & $\begin{array}{l}T . \\
\text { bellerica }\end{array}$ & $\begin{array}{l}\text { E.officinali } \\
s\end{array}$ & S.trifoliatus & $\begin{array}{l}S \\
\text { anacardium }\end{array}$ & $\begin{array}{l}\text { B.frandos } \\
a\end{array}$ & 9-13years & $14-18$ years & 9-13years & $14-18$ years & 9-13years & $14-18$ years & \\
\hline \multirow[t]{7}{*}{1} & Macronutrients & & & & & & & & & & & & & \multirow{23}{*}{$34 ; 35$} \\
\hline & Sodium & 1.56 & 2.34 & 3.13 & 1.71 & 1.81 & 1.8 & & & & & & & \\
\hline & Potassium & 4.04 & 3.37 & 3.07 & 3.50 & 1.73 & 5.69 & & & & & & & \\
\hline & Calcium & 0.30 & 0.34 & 0.23 & 0.69 & 0.33 & 0.54 & $1.250 \mathrm{mg}$ & $1.250 \mathrm{mg}$ & $700 \mathrm{mg}$ & $1.250 \mathrm{mg}$ & $1.250 \mathrm{mg}$ & $700 \mathrm{mg}$ & \\
\hline & Phosphorus & 0.81 & 3.50 & 2.05 & 0.52 & 6.20 & 1.19 & $1.300 \mathrm{mg}$ & $1.300 \mathrm{mg}$ & $1.00 \mathrm{mg}$ & $1.300 \mathrm{mg}$ & $1.300 \mathrm{mg}$ & $1.00 \mathrm{mg}$ & \\
\hline & Magnesium & 0.26 & 0.36 & 0.20 & 0.41 & 0.37 & 0.87 & $8 \mathrm{mg} / \mathrm{d}$ & $15 \mathrm{mg} / \mathrm{d}$ & $18 \mathrm{mg} / \mathrm{d}$ & $8 \mathrm{mg} / \mathrm{d}$ & $11 \mathrm{mg} / \mathrm{d}$ & $8 \mathrm{mg} / \mathrm{d}$ & \\
\hline & Nitrogen & 3.55 & 3.40 & 4.36 & 8.82 & 2.17 & 8.06 & - & - & - & - & - & - & \\
\hline \multirow[t]{5}{*}{ II } & Micronutrients & & & & & & & & & & & & & \\
\hline & Zinc & 88.00 & 50.83 & 46.35 & 204.86 & 89.71 & 40.93 & $8 \mathrm{mg} / \mathrm{d}$ & $9 \mathrm{mg} / \mathrm{d}$ & $8 \mathrm{mg} / \mathrm{d}$ & $8 \mathrm{mg} / \mathrm{d}$ & $8 \mathrm{mg} / \mathrm{d}$ & $11 \mathrm{mg} / \mathrm{d}$ & \\
\hline & Copper & 40.94 & 65.06 & 65.06 & 38.73 & 29.24 & 89.97 & $700 \mathrm{mg} / \mathrm{d}$ & $890 \mathrm{mg} / \mathrm{d}$ & $900 \mathrm{mg} / \mathrm{d}$ & $700 \mathrm{mg} / \mathrm{d}$ & $890 \mathrm{mg} / \mathrm{d}$ & $900 \mathrm{mg} / \mathrm{d}$ & \\
\hline & Manganese & 23.41 & 27.79 & 565.52 & 115.19 & 561.85 & 680.03 & $1.6 \mathrm{mg} / \mathrm{d}$ & $1.6 \mathrm{mg} / \mathrm{d}$ & $1.8 \mathrm{mg} / \mathrm{d}$ & $1.9 \mathrm{mg} / \mathrm{d}$ & $2.2 \mathrm{mg} / \mathrm{d}$ & $2.3 \mathrm{mg} / \mathrm{d}$ & \\
\hline & Iron & 870 & 294.06 & 139.28 & 264.37 & 910.48 & 19.5 & $8 \mathrm{mg} / \mathrm{d}$ & $15 \mathrm{mg} / \mathrm{d}$ & $18 \mathrm{mg} / \mathrm{d}$ & $8 \mathrm{mg} / \mathrm{d}$ & $11 \mathrm{mg} / \mathrm{d}$ & $8 \mathrm{mg} / \mathrm{d}$ & \\
\hline \multirow[t]{3}{*}{ III } & Heavy metals & & & & & & & & & & & & & \\
\hline & Lead & - & - & - & - & - & - & \multicolumn{6}{|c|}{$5.4 \%$} & \\
\hline & Cadmium & - & - & - & - & - & - & & & $2.9 \%$ & & & & \\
\hline \multirow[t]{7}{*}{ IV } & Proximates (\%) & & & & & & & & & & & & & \\
\hline & Ash & 10.27 & 10.90 & 4.50 & 11.80 & 19.33 & 19.50 & NA & NA & NA & NA & NA & NA & \\
\hline & Moisture & 166.10 & 167.40 & 83.20 & 96.10 & 108.00 & 185.00 & NA & NA & NA & NA & NA & NA & \\
\hline & Fat & 103.50 & 94.42 & 4.50 & 96.50 & 96.50 & 36.00 & NA & NA & NA & NA & NA & NA & \\
\hline & Fiber & 9.61 & 6.24 & 8.11 & 3.00 & 3.00 & 13.28 & 25 to $30 \mathrm{gm}$ & 25 to $30 \mathrm{gm}$ & 25 to $30 \mathrm{gm}$ & 25 to $30 \mathrm{gm}$ & 25 to $30 \mathrm{gm}$ & 25 to $30 \mathrm{gm}$ & \\
\hline & Protein & 8.38 & 6.94 & 2.56 & 3.67 & 3.67 & 1.44 & 44 to $58 \mathrm{gm}$. & 44 to $58 \mathrm{gm}$. & $\begin{array}{l}44 \text { to } 58 \\
\text { gm. }\end{array}$ & $\begin{array}{c}44 \text { to } 58 \\
\text { gm. }\end{array}$ & 44 to $58 \mathrm{gm}$. & $\begin{array}{l}44 \text { to } 58 \\
\text { gm. }\end{array}$ & \\
\hline & Carbohydrates & 9.34 & 20.26 & 150.04 & 100.25 & 100.25 & 53.39 & 55 to $60 \%$. & 55 to $60 \%$. & 55 to $60 \%$. & 55 to $60 \%$. & 55 to $60 \%$. & 55 to $60 \%$. & \\
\hline V & $\begin{array}{l}\text { Nutritive value } \\
\text { (Cal/100mg) }\end{array}$ & 940 & 958.34 & 882.90 & 1174.08 & 1117.08 & 561.90 & & & & & & & \\
\hline
\end{tabular}


Further, Objajinwa et al. (2002) said that mineral contents of plants varies according to composition of soils in which plants is grown. When the heavy metals are not recorded in the samples suggesting that the herbs are collected from unpolluted natural habits and reflect the natural levels of heavy metals. In the present study, the heavy metals were not recorded in the plant samples except Terminalia chebuloa and Terminalia bellerica in which trace of lead and cadmium was recorded. The similar observations were also made by Sarala (2006) ${ }^{46}$ and Shashikumar $(2006)^{47}$ in the plants of Withania somnifera and different species of Dioscorea which were collected from the different habitats of different climatic conditions.

Nutritive values of the medicinal plants which were studied ranged between $294 \mathrm{cal} / 100 \mathrm{gm}$ and $331 \mathrm{cal} / 100 \mathrm{gm}$ in the fruit samples of Emblica officinalis and Terminalia chebula respectively. Donatus Ebere (2005) ${ }^{48}$ studied the components of the nutrients, carbohydrates crude fibres, moisture content and crude protein of ripen fruits of Dennettia tripetala and reported that the caloric value of $480.24 \mathrm{gm}, \mathrm{cal} / 100 \mathrm{gm}$ of fresh fruits. Simultaneously, mineral content of calcium (1.8\%), phosphorus $(0.33 \%)$, potassium $(2.50 \%)$ and magnesium $(0.42 \%)$ and they have justified uses of Dennettia tripetala fruits as food and a drug in herbal medicine in south eastern Nigeria. Further, Indrayana et al. (2005) ${ }^{11}$ tried to evaluate nutritive values of seeds of Nelumbo nucifera, Embelia ribes, Eugenia jambolona and Artocarpus heterophyllus and they have classified plants into food and fodder uses. Deepak Dhyani $(2007)^{49}$ attributed studied basic nutrients of Hippophae rhamnoides population from Uttara Khand, India and said that the nutritive fruit values of fruits and seeds of Seed buckthorn varied in different locations and also emphasized the importance of nutritional values for the development of organic foods and nutritional industries in the state of Uttara Khand. Therefore, the present investigation. Terminalia chebula, Terminalia bellerica and Emblica officinalis are used in the proportion of Triphala an ayurvedic formulation (Naik et al., 2006) ${ }^{22}$. Hence, the present study determination of elemental composition and nutritive values of Terminalia chebula, Terminalia bellerica and Emblica officinalis have important connotation in light of upcoming ayurvedic medicines and plant based pharmaceutical industries of India.

\section{CONCLUSION}

The six plants which are studied in the present investigation, the fruits of Terminalia chebula, Terminnalia bellerica and Emblica officinalis are used in the preparation of triphala, an ayurvedic formulation. The plants have rich in the sources of proximate, nutritive value and elements composition. The results were compared with RDA values all the components are rich in the fruit samples. The fruits of Semicarpus anacardium and Sapindus trifoliatus which belongs to same family Anacardaceae are used in the preparation of ayurvedic formulations and the study is important connotation in light of upcoming ayurvedic medicines and plant based pharmaceutical industries of India.

\section{Acknowledgements}

The authors thank the Chairman, Department of Applied Botany, Kuvempu University, Shankaraghatta, Shimoga.

\section{REFERENCES}

1. Pryor Kimberly. Nutritional strategies to Bolster kinds of immune systems. Vitamin Research News. 2004; 18 (6): 13-21.

2. Trivedi D P, Doll R, Khaw K T. Effect of four monthly oral vitamin D3 (cholecalceferol) supplementation on fractures and mortality in men and women living in the community Randomized double blind controlled trial. BMJ.2003; 326: 469.

3. Zuttermann A, Schleithoff S S, Tenderich G, Berthold H K, Korfer R and Stehle P. Low vitamin D status: A contributing factor in the pathogenesis of congestive heart failure?. J. Am. Call. Cardiol. 2002; 4(1): 5-12.

4. Plotnikoff $G$ A and Quigley J M, Prevalance of severe hypovitaminosis $D$ in patients with persistent, nonspecific musculoskeletal pain, Mayo Clinic Proceedings. 2003; 78(12): 1463-70.

5. Munger $K L$, Zhang $S M$, OReilly $E$, Hernan $M A$, Olek M J, Willett W $C$ and Ascherio A. Vitamin D intake and incidence of multiple sclerosis. Neurology.2004; 62(1): 60-65.

6. Merlino L A , Curtis J, Mikuls T R, Cerhan R, Criswell L A and Saag $K$ G. Vitamin $D$ intake is inversely associated with rheumatoid arthritis, Results from the lowa Women's health study. Arthritis and Rheumatism Published online.2004; 9: 72-77.

7. Colston $\mathrm{K}$,Trabert B and Guy M. Vitamin D receptor gene polymorphisms and breast cancer risk. Clinical Research.2004; 10(16): 22-30

8. Lieberman D A, Prindiville S, Willis D G and Willett W. Risk factors for advanced colonic neoplasia and hyperplastic polyps in asympomatic individuals. JAMA.2003; 290(22): 2959-67.

9. Polek T C and Weigel N L.Vitamin D and prostate. Cancer J. Androl. 2002; 23(1): 9-17.

10. Max H, Pittler and Edzard Ernst. Dietary supplements fro body weight reduction: A Systematic Review. American journal of clinical nutrition. 2004; 79: 529-36.

11. Indrayan A K, Suddep Sharma, Deepak Durgapal, Neeraj Kumar and Manoj Kumar.Determination of nutritive value and analysis of mineral elements for some medicinally valued plants from Uttaranchal. Current Science. 2005; 89: 1252-1254.

12. Ganesh Chandra Jagetia, Shaival Kamalaksh Rao, Manjeshwar Shrinath Baliya and Kiran S, Babu. The evaluation of nitric oxide scavenging activity of certain herbal formulations in vitro : A Preliminary Study. Phytotherapy Research.2004; 18: 561-565.

13. Nail G H, Priyadarshini $\mathrm{K} I$ and Hari Mohan. Free radical scavenging reactions and phytochemical analysis of Triphala, an ayurvedic formulation. Current Science. 2006; 90: 1100-1105.

14. www.google.com. Nutritive value of Triphala components

15. Nadkarni A K. Indian Materia Medicapopular Prakashan. Bombay; 1976.p.147.

16. Mehta B K, Shitut S and Warkhade H.In vitro antimicrobial efficacy of triphala. Fitoterapia.1999; 64: 371-372.

17. Singh P K. Mycotoxin elaboration in Triphala and its constituents. Indian Phytopathol.2003; 56: 380-383.

18. Thakur C P, Thakur B, Singh S, SInha P K and Sinha S K. The ayurvedic medicines, haritaki, anala and bahira reduce 
cholesterol-induced atherosclerosis in rabbits. International Journal of Cardiology.1988; 21: 167-175.

19. Tariq M, Hussain S J, Asif M and Jahan M.Protective effects of fruits of extracts of Emblica officinalis Gaertn. and Terminalia bellerica Roxb. in experimental myocardial necrosis in rats. Indian Journal of Experimental Bilology.1977; 15: 485-486.

20. Kumar P, Kuttan R and Kuttan G, Radio-protective effects of Rasayanas. Indian Journal of Experimental Biology. 1996; 34: 84850 .

21. Naik G H, Priyadarsini $K \mathrm{I}$ and Hari Mohan. Free radical scavenging reactions and phytochemical analysis of triphala, an ayurvedi formulations. Current Science. 2006; 90: 1100-1105.

22. Rukmini $C$ and Udaya Shankar Rao P. Chemical and nutritional studies on Terminalia bellerica Roxb, kernel and its oil. Journal of the American Oil Chemists Society. 2007; 63: 360-363.

23. Ramasundaram Srikumar, Narayanaperumal Jeya, Parthasarathy, Sundaramagalingm Manikandan, Govindarajulu Satyanarayanan and Rathinaswamy Sheeladevi. Effect of Triphala on oxidative stress and on cell mediated immune against noise stress rats, Mol cell Biochem 2006; (2)283: 67-74.

24. http://en.wikipedia.org.Karnataka.

25. Gamble J C. Bishen Singh and Mahendra Pal Singh. Flora of Presidency of Madras Dehradun; 1921.

26. Ramaswamy S N, Radhakrishna Rao M and Govindappa D A. Flora of Shimoga District, Karnataka Prasaranga Manasagangothri Mysore; 2001.

27. Bhat K A. Project report on ecological science Kuvempu University Shankaraghatta. 1995.

28. Venugopal $\mathrm{P} H$. The medicinal plants of Shimoga District Post Graduate Department of Biotechnology (Life science) Kuvempu University; 1993.

29. Kirthikar K R and Basu B D. Indian medicinal plants. Published by Lati Mohan Basu M B; 1774.

30. Kumar A and Purohit S S. Plant physiology. Fundamentals and Applications $2^{\text {nd }}$ ed., Agrobios Jodhpur; 2003.

31. Nadkarni A K, Indian Materia Medica. Popular Prakashan. Bombay 1976.

32. Gali S K, Poleshi C M, Saranganath P A and Dasog G S and (2+1), Department of Soil Science and Agricultural Chemistry College of Agriculture Dharwad; 2000.

33. Chopra S L and Kanwar J S. In Analytical Agricultural Chemistry. Kalyani Publications New Delhi; 1991.

34. Sarala P and Krishnamurthy S R. Monkey jack: underutilized edible medicinal plant, nutritional attributes and traditional foods of Western Ghats, Karnataka. India. J Tradit know.2014; 13 (3): 508518.
35. Krishnamurthy S R and Sarala P 2012. Determination of Nutritive Value of Zizyphus rugosa Lamk : A famine edible fruit and medicinal plants of Western Ghats. J. Nat. Prod. Resour.2012; 3(1): 20-27.

36. Krishnamurthy $S R$ and Sarala P. Proximates nutritive values and mineral components of Withania somnifera (Linn.) Dunal. EJournals Net. 2010; 7(3): 985-996.

37. Onianwa P C, Adetola I G, Iwegbue C M A, OJo M F and Tell O O, Trace Heavy metals composition of some Nigerian beverages and food drinks. Food Chem.1999; 6(66): 275-279.

38. Akhter P M, Akarm SD, Orfi and Ahmed N. Assessment of dietary zinc ingestion in Pakistan. Nutr.2002; 18: 274-278.

39. Akpanyung E O.Proximate and mineral element composition of bouillon cubes produced in Nigeria. Pak. J. Nutr. 2005; 4: 327-329.

40. Gracia E C, Cabrera M L, Lorenzo and Lopez M C. Chromium levels in spices and aromatic herbs. The sci. Total Environ. 2000; 247: 5156.

41. Satter A M, Wahid and Durrani S K. Concentration of selected heavy metals in spices, dry fruits and plant nuts. Plant Foods Hum. Nutr. 1989; 39: 279-286.

42. Ansari T M, Ikram N, Najam-ul-haq M, Fayyaz O, Ghafoor I and Khalid N. Essential trace metals ( $\mathrm{Zn}, \mathrm{Mn}, \mathrm{Cu}$ and $\mathrm{Fe}$ ) levelsin plants of medical importance. J. Biol. Sci, 2004; 4: 95-99.

43. Obiajunwa E I, Adeleke C, Adebajo and Olanrewaju R, Omobuwajo, Essential and trace element contents of some Nigerian medicinal plants. Journal of Radioanalytical and Nuclear Chemistry. 2002; 252(3): 473-476.

44. Al Moarut Olukayode Ajasa, Mulbat Olabsi Bello, Aslata Omotago Ibrahim, Islaka Ajanl Ogunwande and Nureni Olaylle Olawore. Heavy trace metals and macronutrients status in herbal plants of Nigeria. Science Direct. 2003; 85: 67-71.

45. Sarala P. Evaluation of Nutritive Value and Mineral Analysis of Withania somnifera. Department of P.G. Studies in Applied Botany, Kuvempu University; 2006.

46. Kumar Shashi N S. Study on Diversity Dioscorea Linn. and evaluation of mineral elements and nutritive value of Dioscorea 2006

47. Donatus Ebere Okwu and Frank Morah N I. Mineral and nutritive value of Dennettia tripetala fruits. CIRAD EDP Sciences. 2005.

48. Dhyani R K, Rao K S, Kumar, Purohit V K, Manju Sundriyal and Saxena K G. Basic nutritional attributes of Hippophae rhamnoides (Seabuckthorn) populations from Uttarakhand Himalaya India. Current Science. 2007; 92: 1-5.

Source of Support: The author(s) received no financial support for the research, authorship, and/or publication of this article.

Conflict of Interest: The author(s) declared no potential conflicts of interest with respect to the research, authorship, and/or publication of this article.

For any question relates to this article, please reach us at: editor@globalresearchonline.net New manuscripts for publication can be submitted at: submit@globalresearchonline.net and submit_ijpsrr@rediffmail.com 